\title{
Budgetary Control and Performance: the Case of Councils in Mezam and Momo Divisions of Cameroon
}

\author{
Samuel Tanjeh Mukah ${ }^{1}$ (Ph.D.) \\ ${ }^{1}$ Faculty of Economics and Management Sciences, The University of Bamenda, Cameroon \\ Correspondence: Samuel Tanjeh Mukah (Ph.D.), Faculty of Economics and Management Sciences, The University \\ of Bamenda, Cameroon. Tel: 237-677-383-633 E-mail: sammukah2003@yahoo.com
}

Received: September 1, 2018

Accepted: September 24, 2018

Online Published: September 27, 2018

doi:10.5430/bmr.v7n3p36

URL: https://doi.org/10.5430/bmr.v7n3p36

\begin{abstract}
The pursuit of quality service delivery in the public sector management in Cameroon necessitated the decentralisation of public sector management by transferring more power and resources to the local councils. This is in a bid to make them more self-governing. These councils are expected to meet the aspirations of their municipalities by carrying out approved projects efficiently and effectively. In this regard, this paper sets out to investigate the relationship between budgetary control and performance of local councils in Mezam and Momo Divisions of the North West Region of Cameroon, and the challenges these councils encounter in the process of budgetary control. Data was collected through a survey and analysed using the Ordinary Least Square (OLS) estimation technique to regress the relationship between the budgetary control variables and council performance. The empirical results showed that the key budgetary control variables (planning, participation, monitoring and control, motivation, communication, and responsibility) have a positively and statistically significant effect on performance of the councils. Effective performance of local councils in Mezam and Momo Divisions of the North West Region of Cameroon could then be attributed to effective presence of budgetary control requiring the availability of financial resources rationally allocated, qualified and experienced personnel, participation of all responsibility center managers in the planning and control processes, and regular communication and motivation of the council staff.
\end{abstract}

Keywords: budget, control, performance, council

\section{Introduction}

Since 2013 that council elections took place, local governments in the North West region of Cameroon in general and in Mezam and Momo divisions in particular have suffered major setbacks in the management of their scarce material, financial, and material resources. Many projects are either poorly executed or not completed as planned, workers go for months without salaries, and public facilities such as toilets, markets, roads, lights and water are poorly managed. Local councils are strategically situated to understand and address the plight of grass root citizens. No other government structure can play such a crucial role as the local councils.

A local council may be described as a government at the proletarian level. Ojofeitimi (2000) describes a local council or government as a political sub-division of a nation, constituted by law and wields substantial control of local affairs and even has power to impose certain taxes. The governing body of local councils in Cameroon, namely the mayors and their deputies are elected for a five year mandate renewable. In 2004, the Cameroon government announced the empowering of local councils with administrative autonomy.

According to Ojo (2009), local council autonomy has three separate standards: amount of responsibility transferred, the size and elasticity of resources assigned, and the degree of discretion conferred. These standards of autonomy of councils as presented by Ojo (2009) cannot be identified with the councils in Cameroon because the process of decentralisation in Cameroon following Bill $\mathrm{N}^{\circ} 762 / \mathrm{PJL} / \mathrm{AN}$ on the Orientation of Decentralisation No 51/AN promulgated into law on the $22^{\text {nd }}$ of July 2004 remains dawdling.

It is no news that councils or local governments in Cameroon have always used budgets and budgetary controls to plan, organise, direct and control their operations. In a municipality, budget sessions are held by the mayor together with the councillors, and the supervisory authority who is the district officer. For the city councils, the government 
delegate chairs such budget sessions. These local governments are empowered to collect revenue and also benefit from government subventions, and grants to execute local projects.

Lately, there has been an increasing call for municipalities to be more autonomous and to properly address the needs of their people. Budget and budgetary control usually constitute the pivot of any vibrant profit, surplus, or community development oriented organisation. It would appear that where budgetary control is not effective or absent, the organisation falls short of attaining its objectives for the period.

Budgeting is a key policy instrument for public and private organisational management (Lambe et al. 2015). A budget has been defined by Lucey (2008) as a plan of action expressed in monetary terms for a future period. It deals with resource servicing and allocation to attain the objectives of an organisation. Successful budgeting according to Hingorani and Ramanathan (2007) requires absolute support and enthusiasm by top management. When such a budget is passed or adopted, and the implementation phase starts, budgetary control sets in to start comparing the planned activities and results with the actual activities and results. In this way, any differences considered significant are investigated and remedial action put in place.

Despite the interest in budgeting over the years, budgetary control has not seemingly picked up the same steam. This is regrettable given that budgetary control is widely recognised as a key instrument for resource allocation to specific recurrent and development activities (Adongo and Jagongo, 2013). An organisation may have a well drafted budget and still fails to attain its objectives. This could be as a result of several challenges; but in general it suggests an ineffective budgetary control. Poor management as well has been identified by some schools of thought to be the cause of local governments performing below expectation (Ojo, 2009).

According to Coker and Adams (2012), finance and prudent management constitute the bedrock of effective functioning of local governments. Ojo (2009) asserts that apart of capital, local governments also need knowledgeable and skilled personnel to manage their usually scarce financial resources. Such personnel are inevitable in carrying out effective budgetary control as a pivotal tool of sound financial management.

Local councils in Cameroon are since 2004 supposed to be autonomous, and are expected to increasingly execute the recurrent and capital projects of the councils much more successfully. Cameroon faces the challenge of running a sound government accounting system that guarantees accountability and transparency (Mukah, 2016). Many local councils are unable to fully or significantly execute their projects effectively, hence unable to attain all their objectives. They fail to satisfy their citizenry at the grassroots despite the fact that they may draft and adopt impressive budgets. Against this backdrop, the paper attempts an investigation into effective budgetary control and performance of local councils. To carry out such an exercise, the following research questions were set:

a) What relationship exists between budgetary control and performance in the local councils of Mezam and Momo divisions of the North West Region of Cameroon?

b) What are the challenges associated with budgetary control in the local councils of Mezam and Momo divisions of the North West Region of Cameroon?

c) How can council performance be improved through the use of budgetary control measures?

The main objective of the paper was to investigate if there is any relationship between budgetary control and performance in the local councils of Mezam and Momo divisions of the North West Region of Cameroon. The specific objectives were to:

a) Identify the relationship between budgetary control and performance of local councils in Mezam and Momo divisions of the North West Region of Cameroon

b) Identify the challenges associated with budgetary control and performance of local councils in Mezam and Momo divisions of the North West Region of Cameroon

c) Seek ways to improve council performance through budgetary control measures

The rest of the paper is structured to give a review of related literature, the methodology to investigate the relationship between budgetary control and performance of the local councils, discussion of results, policy implications and a conclusion.

\section{Literature Review}

Performance is a germane concept in this study. Citing Stoner (2003), Arthur et al. (2013) describe performance as the ability to operate efficiently, profitably, survive, grow, and respond to environmental opportunities and threats. Such an ability to operate as described above presumably includes timely completion and delivery of quality projects, 
payment of staff, suppliers and service providers. Millichamp (1997) attributes performance to the quality of management and the rightness of decision making. This suggests that meeting up with targets portrays successful performance. Ghobadian (1994) considers the measurement of service performance to be crucial in any drive to improve productivity.

The Oxford Dictionary of Accounting (2003) defines a budget as 'a financial or quantitative statement, prepared prior to a specified accounting period, containing the plans and policies to be pursued during that period. It is used as the basis for budgetary control.' Surajkumar (2005) describes a budget as an allocation mechanism that strives to maximise public expenditure contribution to national welfare. Luke 14:28-30 explains this budget concept with the example of a man building a tower, how he needs to do costs calculation to ascertain that he has enough resources to realise the project. A budget therefore provides a focus for the organisation (Bartle, 2008).

Quoting Otley and Merchant (1990), Kyei et al (2015) describe the budgetary system as an interactive cycle moving between targeted desirable performance and estimates of feasible performance, thus converging to a feasible and acceptable plan. In line with this, Lambe et al. (2015) affirm that the budgetary system of every organisation provides basis to determine the source, allocation and rational use of funds by those given the responsibility to manage an organisation and achieve its goals. The process of budgeting therefore entails planning and decision making. Presumably, budgeting allocates scarce resources in a way that marginal expenditures generate optimum marginal benefits.

Control is another important concept in this study. According to Lucey (2008), control is concerned with the efficient use of resources to achieve a previously determined objective, or set of objectives contained within a plan. A plan being the method the entity has decided to attain the objectives most effectively. Control is the activity that measures variations from planned performance. It provides information feedback loops, which may necessitate corrective action (if need be) to maintain or modify the original plans. For example, a negative feedback leads to corrective action in the opposite direction to that of the deviation. Thus, planning and control are inextricably linked, making the difference between the two concepts blurred. The main control systems are budgetary control and standard costing.

The Chartered Institute of Management accountants (CIMA) Official Terminology (2005) describes the concept budgetary control as the establishment of budgets relating to the responsibilities of executives of a policy and the continuous comparison of the actual results with the budgeted results either to secure by individual action the objective of the policy or to provide a basis for its revision. Lucy (2008) confirms this definition by describing budgetary control to involve the establishment of budgets, continuous comparison of actual and budgeted activities or results, budget revision if circumstances change, and being able to place responsibility for attaining the budget or not. Budgetary control thus involves comparing the actual results with the planned results and reporting on the variance. According to Siyanbola (2013) budgetary control relates expenditure to the personnel responsible for the various expenditures at the various responsibility centers. Budgetary control entails responsibility accounting. However, responsibility accounting should be applied with caution. The Institute of Chartered Accountants India (ICAI) (2014) asserts that a manager who exceeds the budgeted amount for an expenditure should not be hastily sanctioned or corrected without proper investigation. It argues further that surpass of the budget amount could have been a result of the manager not willing to buy inferior materials.

Kaplan and Norton, (1992) consider the budget and budgetary control to be very useful to an organisation because they ensure efficiency in the working conditions of the organisation. This occurs when targets are set out in the organisation and resources made available for all sectors of the organisation to work diligently towards achieving the set targets. The primary function of budgetary control is to serve as a guide in financial planning operations (Abernethy and Stoelwinder, 1995). In this regard, Mukah (2016) asserts that approved budgets be incorporated into the management information system in order to ensure informed financial decision making. Accordingly, for this to be effective emphasis should be put on the availability of constant and stable electricity supply, and adequate and qualified management information system staff. According to ACCA (2007/2008) the main aims of a budgetary control system are to plan for the future in line with organisational objectives, control costs by comparing the plan with the actual results and taking corrective action where necessary. Furthermore, to coordinate and facilitate centralised control with decentralised activities, communicate targets of the organisation with the managers, motivate managers with bonuses by encouraging them to beat targets, evaluate management performance with respect to realising the budget, and to act as a way of authoring expenditure. A budgetary control system ensures profit maximisation since it ensures proper planning and coordination of the different functions of an organisation, proper control over revenue and capital expenditures, and proper allocation of resources, Preetabh (2010). 
The Cameroon government is conscious of the role played by budgetary control. This explains why decree No. 2008/365 section 9, article 54 of November 8, 2008 that modified and completed decree No. 2004/320 of December $8^{\text {th }} 2004$, created a division of budgetary control and audits in the Ministry of Finance. In addition to carrying out audits of public financial management, the division does evaluation of budget executions in the public sector establishments (Mukah, 2015).

The assertions above suggest that budgets and the budgeting process have become a mainstay, given that a sound budget provides both financial and operational benefits. However, the process does not go without some myriad of challenges that can stifle the achievement of the full benefits of budgets and budgetary control unless adequately handled. Margah (2005) contends that there are new competitive realities and rapidly changing environments and complexities that require management to apply flexible and adaptable budgetary planning and control systems. According to him if management is not aware of this, it may find itself in a situation where a budget becomes outmoded within the budget year before its application begins.

Management and employee acceptance of the budget could also be a challenge. It is not easy to cause every worker to be fully committed. Employees not committed may not strive hard enough to attain the budget goals and objectives. According to Perrin (2012), a budgetary control programme will be successful if it has a complete acceptance and support of the persons who occupy important management positions. If lower personnel notice that top management is not serious about budgetary controls, they put up a nonchalant attitude towards the system.

The theoretical literature reviews three theories related to the study namely: the theory of performance, Walker's progressive theory, and the agency theory. The theory of performance develops and relates six foundational concepts (context, level of knowledge, level of skills, level of identity, personal factors, and fixed factors) to form a framework that can be used to expound performance and performance improvements. To perform is to produce valued results by an individual or a group of people engaging in a collaborative effort. Performance may be described as a journey and not a destination; and a level of performance is seen as a location in the journey. The location is influenced by the performer's mind-set, immersion in an enriching environment, and engagement in reflective practice (Elger, 2007).

On the other hand, the Walker's progressive theory is concerned with the standard of living in cities and the ability to pay for it. A city's standard of living was assessed amongst other things by the number and quality of government services provided. Consequently, Walker's progressive budget theory anchored on the premise that the means to decide how to allocate between options was through the "utilitarian ideal" or indifference point in economic theory as applied to government budgets (Walker, 1930)

The agency theory explains this relationship between the principal and the agent in an organisation. The owners of an organisation are the principal while the managers are the agents (Donaldson and Davis, 1991; Guangdi and Fulwood, 2013). With the local councils, the citizenry comprising the municipality in general and the tax payers in particular are akin to the principal or owners of the public resources. The mayors and the councillors are the agents who work for the interest of the principal. The tax payers and the public have the right to seek accountability and transparency from the local government that on their behalf manages the scarce resources (Mukah, 2016).

The empirical literature reviews the investigations and findings in Ernest Chemist in Ghana, Cadbury Nigeria Plc, Kigali Serena hotel in Rwanda, and International Breweries Plc in Nigeria. Badu (2011) got the perception of budgeting experts in Ernest Chemist, a pharmaceutical company based in Ghana which used budgets as a management tool. The study revealed ethical issues as some of the major challenges in the budget and budgetary control system. Reinforcement of good morals amongst staff was therefore identified to overcome the challenge.

Siyanbola (2013) did a study of the impact of budgeting and budgetary control on the performance of Cadbury Nigeria Plc a manufacturing company in Nigeria. One of his main findings was that budgeting and budgetary control was too complex for the people to understand. He then recommended that budgeting and budgetary control should be simplified for the staff to understand in order to become more committed.

Herelimana (2017) in a study carried out in Kigali Serena hotel in Rwanda to examine the effect of budgetary control on financial performance, contended that there is a strong positive relationship between budgetary control methods and financial management expressed through returns on investment.

Balogun et al., (2015) carried out a preliminary investigation on budgetary control and organisational performance using International Breweries Plc in Nigeria as a case study. Their findings revealed among other things that budgetary control has a strong relationship with organisational performance since a budget itself forms the basis for 
decision making, performance evaluation, and resource allocation. They assert further that budgetary control provides structural support for organisational performance.

\section{Methodology}

Mezam is one of the 7 administrative divisions that make up the North West Region of Cameroon. Bamenda is the administrative capital of Mezam division. Mezam division has 7 subdivisions namely: Bafut, Bali, Bamenda 1, Bamenda 2, Bamenda 3, Santa, and Tubah. Each of these subdivisions has a local government called council and named after the subdivision. Each of the local councils is headed by an elected official called a mayor, assisted by deputy mayors (Governor's office, 2018). However, in addition to these 7 sub divisional councils in Mezam division, there is a city council called Bamenda city council. It is headed by an appointee of the government called government delegate. The city council through its government delegate indirectly controls Bamenda 1, 2 and 3 councils. For instance, it manages the granting of building permits to anyone building in Bamenda 1, Bamenda 2, and Bamenda 3 councils.

Momo division as well is an administrative division in the North West Region. It has five sub divisions namely: Batibo, Mbengwi, Ngie, Njikwa, and Widikum. Each of these sub divisions is locally governed by a local council named after the divisional name. The administrative capital of Momo division is Mbengwi (Governor's office, 2018). All the local councils in Momo division are run by elected official called mayors.

Primary data were collected in all the 12 local councils in Momo and Mezam Divisions in the North West Region from respondents through a questionnaire. The respondents in each council were the finance officer, accountant, pay master, secretary general, mayor and or deputies. They were purposively identified to be respondents given their indebt understanding of the situation under investigation (Adongo \& Jagongo, 2013). These participants are involved in developing and implementing the budget, and also involve in the budgetary control system in the council. Consequently, they were deemed competent to serve as respondents in the survey.

The questionnaire was established to enable respondents to freely give their perceptions, stating whether they strongly disagree, disagree, not decided, agree or strongly agree with each relationship portrayed by the variable of budgetary control with the council performance. The Special Package for Social Sciences (SPSS) 20 was used to analyse the descriptive results. Stata 12 was used to run an Ordinary Least Square (OLS) regression of the relationship between the budgetary control variables and council performance. The dependent variable was performance, while the independent variables were the budgetary control variables namely planning, motivation, communication, resource allocation, cost control, and responsibility accounting.

The model constructed was: $\mathrm{CP}=\mathrm{f}\left(\mathrm{X}_{1}, \mathrm{X}_{2}, \mathrm{X}_{3}, \mathrm{X}_{4}, \mathrm{X}_{5} \mathrm{X}_{6}\right)$

The econometric expression is as follows:

$\mathrm{CP}_{\mathrm{i}}=\beta_{0}+\beta_{1} \mathrm{X}_{1 \mathrm{i}}+\beta_{2} \mathrm{X}_{2 \mathrm{i}}+\beta_{3} \mathrm{X}_{3 \mathrm{i}}+\beta_{4} \mathrm{X}_{4 \mathrm{i}}+\beta_{5} \mathrm{X}_{5 \mathrm{i}}+\beta_{5} \mathrm{X}_{6 \mathrm{i}}+\lambda_{\mathrm{i}}$

Where: $\mathrm{CP}=$ Council Performance

$\beta_{0}=$ Intercept

$\beta_{1}, \beta_{2}, \beta_{3}, \beta_{4}$, and $\beta_{5}=$ Parameters coefficients to be estimated for the variables in the regression equation,

$\lambda=$ Error or disturbance term with its assumed normality

$\mathrm{X}_{1}=$ Planning, $\mathrm{X}_{2}=$ Monitoring and Control, $\mathrm{X}_{3}=$ Participative Budgeting,

$\mathrm{X}_{4}=$ Responsibility, $\mathrm{X}_{5}=$ Motivation, $\mathrm{X}_{6}=$ Communication

The independent variables: planning, monitoring and control, participative budgeting, responsibility, motivation and communication, are variables of budgetary control used in this study which were measured using the various questions responded to by the respondents in the questionnaire. For the purpose of regression, the question items for each variable were summed and the average obtained to use in the analyses. The computer programme STATA 12.0 version was used to analyse the data. Correlation and regression analysis were used to test the effect of budgetary control on council performance. The Model coefficients were estimated using, the Ordinary Least Square (OLS). The a-priori expectation of the estimated parameters was that $\beta_{1}, \beta_{2}, \beta_{3}, \beta_{4}, \beta_{5}$, and $\beta_{6}$ will be greater than zero. This will suggest that there exist a positive functional relationship between council performance and the budgetary control parameters. 


\section{Data Presentation and Analysis}

The descriptive results were presented in Appendix A titled, Components of budgetary control and performance of the councils. Appendix A shows how the respondents used each variable presented by the researcher to perceive its effect on the performance of the council. Respondents gave their perceptions as: strongly disagree, disagree, not decided, agree or strongly agree with each variable capturing the performance of the council.

On the other hand, Appendix B presents the budgetary control challenges faced by the councils in Mezam and Momo divisions. The major challenges were: inadequate financial resources, inadequate qualified and experienced finance personnel, lack of resource management knowledge by some mayors, workers' poor work attitude, financial improprieties and unlawful interference by some supervisory authorities.

A summary of the descriptive statistics is given in table 1. It reveals that all the variables are not having the same number of observations. This is because some respondents could not respond to some of the questions. Also, from table 1, the mean of the performance variable is 3.366 and the maximum and minimum value is 5 and 1 respectively. Its standard deviation is 1.494 indicating a low deviation from the mean. The mean value of responsibility is 2.893 and the maximum and minimum values are 5 and 1 respectively, and the standard deviation is 1.359 implying a small deviation from the mean. Motivation is the variable with the smallest mean of 2.835 and largest standard deviation of 1.729 .

Table 1. Summary of descriptive statistics

\begin{tabular}{llllll}
\hline Variables & Observations & Mean & $\begin{array}{l}\text { Standard } \\
\text { deviation }\end{array}$ & Minimum & Maximum \\
\hline Performance & 94 & 3.366 & 1.494 & 1 & 5 \\
Planning & 96 & 2.942 & 1.586 & 1 & 5 \\
Monitoring and Control & 82 & 3.030 & 1.405 & 1 & 5 \\
Participative Budgeting & 92 & 3.826 & 1.328 & 1 & 5 \\
Responsibility & 95 & 2.893 & 1.359 & 1 & 5 \\
Motivation & 95 & 2.835 & 1.729 & 1 & 5 \\
Communication & 95 & 3.634 & 1.586 & 1 & 5 \\
\hline
\end{tabular}

Source: Author's computation

Detail results of the item responses for each of the variables are presented in the Appendix.

The correlation results are presented in table 2. They show that there exist both positive and negative relationships between the variables involved in the study. These results also show that the correlation between one variable and itself is equal to 1 or perfectly collinear. Table 2 shows the correlation between the pairs of variables included in the estimation. The P-values of the correlations are presented in parentheses. The pairwise correlations are very significant in most cases. 
Table 2. Pairwise correlation Matrix

\begin{tabular}{|c|c|c|c|c|c|c|c|}
\hline Variable & $\begin{array}{l}\text { Perfor-ma } \\
\text { nce }\end{array}$ & Planning & $\begin{array}{l}\text { Monitoring } \\
\text { and } \\
\text { Control }\end{array}$ & $\begin{array}{l}\text { Participative } \\
\text { Budgeting }\end{array}$ & $\begin{array}{l}\text { Respon-sib } \\
\text { ility }\end{array}$ & Motivation & $\begin{array}{l}\text { Communic } \\
\text { ation }\end{array}$ \\
\hline Performance & 1 & & & & & & \\
\hline Planning & $\begin{array}{l}0.0061 \\
(0.0521)\end{array}$ & 1 & & & & & \\
\hline $\begin{array}{l}\text { Monitoring and } \\
\text { Control }\end{array}$ & $\begin{array}{l}0.3538 \\
(0.0003)\end{array}$ & $\begin{array}{l}0.3231 \\
(0.0010)\end{array}$ & 1 & & & & \\
\hline $\begin{array}{l}\text { Participative } \\
\text { Budgeting }\end{array}$ & $\begin{array}{l}0.5269 \\
(0.0000)\end{array}$ & $\begin{array}{l}0.2182 \\
(0.0518)\end{array}$ & $\begin{array}{l}0.4741 \\
(0.0000)\end{array}$ & 1 & & & \\
\hline Responsibility & $\begin{array}{l}0.2942 \\
(0.0031)\end{array}$ & $\begin{array}{l}0.2702 \\
(0.0068)\end{array}$ & $\begin{array}{l}0.3397 \\
(0.0006)\end{array}$ & $\begin{array}{l}0.1088 \\
(0.3366)\end{array}$ & 1 & & \\
\hline Motivation & $\begin{array}{l}0.4453 \\
(0.0000)\end{array}$ & $\begin{array}{l}0.1528 \\
(0.1290)\end{array}$ & $\begin{array}{l}0.4149 \\
(0.0000)\end{array}$ & $\begin{array}{l}0.3000 \\
(0.0069)\end{array}$ & $\begin{array}{l}0.1588 \\
(0.1164)\end{array}$ & 1 & \\
\hline Communication & $\begin{array}{l}0.3362 \\
(0.0006)\end{array}$ & $\begin{array}{l}0.4451 \\
(0.0000)\end{array}$ & $\begin{array}{l}0.0074 \\
(0.9420)\end{array}$ & $\begin{array}{l}0.3481 \\
(0.0016)\end{array}$ & $\begin{array}{l}0.4880 \\
(0.0001)\end{array}$ & $\begin{array}{l}0.1161 \\
(0.2501)\end{array}$ & 1 \\
\hline
\end{tabular}

Source: Author's computation

The results in Table 2, show that there exist a positive correlation between the independent variables (planning, monitoring and control, participative budgeting, responsibility, motivation and communication) and the dependent variable. This shows that an increase in these variables will result to an increase in the performance of these councils. Table 2 also shows the correlation between the independent variables. The results show that there is a positive correlation among the independent variables. This means that the measures of budgetary control are all positively correlated among each other. This makes them complementary to each other.

The correlation among the independent variables could also be used as a prelude to investigate the presence of multicollinearity. If the correlation between a pair of variables is less than 0.5 , it means that the correlation is weak. A weak correlation shows potentially that multicollinearity is not a problem as observed in the table 2 . However, to further verify and support the results of the pairwise correlation, the Variance Inflation Factor (VIF) test for multicollinearity was carried out, the results presented in table 3 .

Table 3. Variance inflation factor (VIF)

\begin{tabular}{lll}
\hline Variable & VIF & $\mathbf{1 / V I F}$ \\
\hline Planning & 1.54 & 0.650088 \\
Monitoring and Control & 1.41 & 0.707371 \\
Responsibility & 1.30 & 0.766325 \\
Motivation & 1.26 & 0.795556 \\
Communication & 1.23 & 0.811048 \\
Participative Budgeting & 1.16 & 0.862298 \\
Mean VIF & 1.32 & \\
\hline
\end{tabular}

Source: Author's computation

The results in table 3 show that the highest VIF value is 1.54 , with an average of 1.32. This is therefore less than the threshold of 2.5. This means that multicollinearity is not a problem among the independent variables used in the estimation. 


\section{Discussion of Results}

The regression results to determine the effect of budgetary control on financial performance are presented in table 4 . The coefficient of the variable planning, shows that there is a positive relationship between planning and performance of selected councils in North West Region. The planning coefficient of 0.6449 indicates that an increase in planning by 1 unit will lead to an increase in performance by 0.6449 . This effect is statistically significant at the $1 \%$ level of significance. Thus, the planning variable is an important policy instrument used in the estimation. This result is consistent with the assertion of Abernethy and Stoelwinder (1995) that the primary function of budgetary control is to serve as a guide in financial planning operations. It also validates the finding of Preetabh (2010) which showed that budgetary control should ensure performance since it warrants proper planning.

This result further supports the contention of Perrin (2012) that budgetary control becomes successful if it has a complete acceptance and support of the persons who occupy important management positions. This suggests that for this to happen they would have been actively involved in the planning process. Furthermore, making reference to the theory of performance reviewed earlier that the level of performance is influenced among other things by the performer's mindset (Elger, 2007), it becomes obvious that where planning excludes some responsibility center managers, a negative mindset may creep in slowly in them, and become a toxic habit that affects the way they perform.

Table 4. Regression Results

\begin{tabular}{|c|c|c|c|c|c|c|}
\hline Source & SS & Df & MS & & \multirow{2}{*}{\multicolumn{2}{|c|}{ Number of observations $=80$}} \\
\hline Model & 128.54895 & 6 & $\begin{array}{l}\text { MS } \\
21.42483\end{array}$ & & & \\
\hline Residual & 23.44783 & 73 & \multicolumn{2}{|l|}{0.32120} & \multicolumn{2}{|c|}{ Prob $>F=0.0000$} \\
\hline \multirow[t]{3}{*}{ Total } & 151.99678 & 79 & 21.74603 & & \multicolumn{2}{|c|}{$\mathrm{R}$-Square $=0.8457$} \\
\hline & & & & & \multicolumn{2}{|c|}{ Adj R-Squared = 0.8331} \\
\hline & & & & & \multicolumn{2}{|c|}{ Root MSE $=0.5667$} \\
\hline \multicolumn{3}{|l|}{ Variable } & Coefficients & $\begin{array}{l}\text { Standard } \\
\text { Error }\end{array}$ & T-statistics & P-Value \\
\hline \multicolumn{2}{|l|}{ Constant } & \multicolumn{2}{|r|}{1.4542} & 0.2778 & 5.234 & 0.000 \\
\hline \multicolumn{2}{|l|}{ Planning } & \multicolumn{2}{|r|}{0.6449} & 0.186646 & 3.46 & 0.004 \\
\hline \multicolumn{2}{|c|}{ Monitoring and Control } & \multicolumn{2}{|r|}{0.8976} & 0.47733 & 1.88 & 0.074 \\
\hline \multicolumn{2}{|c|}{ Participative Budgeting } & \multicolumn{2}{|r|}{0.4678} & 0.176248 & 2.65 & 0.021 \\
\hline \multicolumn{2}{|c|}{ Responsibility } & \multicolumn{2}{|r|}{0.0688} & 0.115196 & 0.60 & 0.561 \\
\hline \multicolumn{2}{|c|}{ Motivation } & \multicolumn{2}{|r|}{0.2749} & 0.129668 & 2.12 & 0.054 \\
\hline \multicolumn{2}{|c|}{ Communication } & \multicolumn{2}{|r|}{0.3860} & 0.165789 & 2.33 & 0.037 \\
\hline
\end{tabular}

Source: Author's computation

The coefficient of monitoring and control is also positive. This shows that an increase in monitoring and control will result to an increase in performance of councils. The result precisely shows than an increase in monitoring and control by one unit will result to an increase in performance by 0.8976 . This effect is statistically significant at the 10 percent level of significance. Monitoring and controlling the budget of the council makes council workers to become more conscious of their responsibilities, so become more performant.

The result for participative budgeting shows that there is a positive effect of participation on performance. This implies that an increase in participation by one unit increases the performance of councils by 0.4678 units. This effect is statistically significant at the 5 percent level of significance. Thus, participation of employees in the process of budget preparation also motivates them to achieve budget goals (Hansen et al., 2003). In fact, Hansen et al, (2003) advocates for full participation and asserts that all individuals responsible for achieving results should be consulted in the formulation of budgets. No system of budgetary control can succeed without the mutual understanding of superiors and subordinates. Participation assures full co-operation and commitment for making budgets successful. Participation also makes budgets realistic and workable. 
Communication is seen to have a positive relationship with council performance. The coefficient for communication is 0.3860 showing that if there is an increase in communication by 1 unit, performance of councils will increase by 0.3860 . This result is statistically significant at $5 \%$ level. Sound communication brings about understanding and acceptance of the budgeting and budgetary control system. This result is confirmed by Perrin (2012) who avowed that a budgetary control programme will be successful if it has a complete acceptance and support of the persons who occupy important management positions. This can only happen if there exists sound communication system in the organisation. Sound communication entails regular meetings, feedbacks, and follow-ups. In reviewing Walker's progressive theory, it was revealed that a city's standard of living is assessed amongst other things by the number and quality of government services provided (Walker, 1930). If communication of such local government services is effective, it could positively influence the commitment level of the staff which culminates in better performance. In addition, effective communication of council services to the public could increase council revenue needed for improved performance because the tax payers understand why they pay the council taxes.

Motivation on its part indicates a positive relationship with performance of the councils. The coefficient of motivation is 0.2749 , indicating that 1 unit change in motivation will increase performance by 0.2749 , and this result is significant at $10 \%$ level. This is in consonance with the avowal that budgetary control motivates managers with bonuses by encouraging them to beat targets (ACCA, 2007/2008). Meeting or beating targets indubitably improves council performance.

The responsibility coefficient gives a positive relationship with the performance of councils too. Its coefficient is 0.0688 indicating that if responsibility accounting changes by 1 unit, performance of councils will increase by 0.0688 units. This result is statistically insignificant at a $10 \%$ level of significance. The positive coefficient obtained in this study is in support of the result obtained by Siyanbola (2013). Siyanbola (2013) edicts that budgetary control relates expenditure to the individuals who are responsible for the execution of the expenditures at the various responsibility centers thus making them more efficient and effective.

The coefficient of the constant term is 1.4542 indicates that if all the independent variables included in this study were considered to have any effect on the dependent variable (performance), performance of councils will be 1.4542 unit. The intercept coefficient is significant at all levels.

The value of the goodness of fit measured by the F-statistics is 66.70 in table 4 . This is highly significant at the $1 \%$ level of significance indicating that the independent variables jointly explained the performance of councils. Thus the overall model was therefore well fitted for the study. The value of the adjusted R-squared indicates the degree of variation in performance explained by the independent variables. The value of adjusted $\mathrm{R}^{2}$ is 0.8331 indicating that $83.31 \%$ of the variation in the performance of councils is attributed to changes in the variables used in the model, while $17.69 \%$ variations in councils performance is caused by variables not included in the model.

The result to validate the assumption of constant variance conducted using the Breusch Pagan test is reported in table 5.

Table 5. Breusch-Pagan/Cook-Weisberg test for heteroskedasticity

\begin{tabular}{l}
\hline $\mathrm{H}_{0}$ : Constant variance \\
\hline Variables: Fitted values of performance \\
$\mathrm{Chi}^{2}(1)=0.28$ \\
\hline Probability $>\mathrm{Chi}^{2}=0.5936$ \\
\hline
\end{tabular}

Source: Author's computation

The result indicates that the test statistics is 0.28 with a probability value of 0.5936 . This is an indication that there is constant variance; hence no problem of heteroscedasticity exists. This implies that the standard errors obtained are efficient. The results obtained are best, linear, unbiased and efficient (BLUE).

\section{Policy Implications and Conclusion}

The paper examined the budgetary control and performance of councils in Mezam and Momo divisions of the North West region of Cameroon. The findings complement the theoretical and empirical evidence reviewed that budgetary control improves performance of local governments or councils because it serves primarily as a guide in financial planning operations in the local councils as demonstrated by the councils of Mezam and Momo divisions. Councils are encouraged to carry out participative budgeting in order to assure full co-operation and commitment of all the staff, thus making the budgets realistic, workable, and successful. Budgetary control generates monitoring and 
control of budget execution, motivation of council workers, good communication of council objectives, plans and budgets, and responsibility by every responsibility center manager. All these culminate in enhanced council performance.

Despite the positive effects of budgetary control on performance of councils, there are challenges. The key ones perceived in these councils are inadequate qualified and experienced finance personnel, inadequate financial resources, low commitment of some council workers, unlawful interference by some supervisory authorities (i.e. the district officers appointed by the central government), and inadequate resource management knowledge by some of the mayors.

To handle these challenges, and for the government to effect meaningful decentralisation of power and management to the local governments, it should as a matter of urgent importance assist them in having trained personnel and financial resources to motivate staff with better remuneration and material resources to perform better. The government should allow the councils full autonomy to manage their affairs and give account to their electorate. The supervisory authorities called district officers should be advised to refrain from overbearing over some of these councils. Great efforts should be made by the council managers to discourage the councils from over dependence on central government subsidies. They should put in place good policies to attract investments in areas such as agriculture and craftsmanship. Budgets and budgetary control seminars for the mayors should be a regular feature especially when they are newly elected into office.

\section{References}

Abernethy M.A. \& Stoelwinder J. (1995). The role of professional control in the management of complex $\begin{array}{lllll}\text { organisations, Accounting, } & \text { Organizations }\end{array}$ https://doi.org/10.1016/0361-3682(94)E0017-O

ACCA. (2007/2008). Paper F2 Management Accounting. Great Britain, Kaplan Publishing.

Adonjo K.O. \& Jagongo Ambrose. (2013). Budgetary control as a measure of financial performance of State corporations in Kenya. International Journal of Accounting and Taxation, 1.

Arthur, S., Abanis, T., Eliab, B., \& Sumil, N. (2013). Financial performance in the selected microfinance institutions in Uganda. International Journal of Engineering Research and Technology (IJERT), 2.

Badu, D. (2011). An investigation of budgeting and budgetary Control at Ernest chemist. Retrieved July 2018 from www.theseus.fi/handle/10024/36754

Bartle, J.R. (2008). Applying pragmatism to public budgeting and financial management. Texas State University.

Balogun, A., Mamidu, A.I., \& Owuze, C.A. (2015). Budgetary control and organisational performance. Journal of Educational Research in National and Social Sciences, 1(1).

Blocher, F. J. \& Chen, K. H. (2002). Cost and Management: A Strategic Emphasis. $2^{\text {nd }}$ Ed., New York, Mc Graw-Hill International.

Bouillon, M. L. (2006). The economic benefit of goal congruence and implications for management control systems. Journal of accounting and public policy, 7-8. https://doi.org/10.1016/j.jaccpubpol.2006.03.003

Bricki, N. (2007). A guide to using qualitative research methodology. Retrieved February 2018 from http://www.fieldresearch.msf.org

Chartered Institute of Management Accountants Official Terminology. (2005). Retrieved July 2018 from www.worldcat.org/title/cima-official-terminology/oclc/155126995

Coker, M.A. \& Adams J.A. (2012). Challenges of Managing Local Government Finance in Nigeria. Research on Humanities and Social Sciences, 2(3).

Elgar, D. (2007). The Theory of Performance. Retrieved July 2018 from https://www.webpages.uidaho.edu/ele/scholars/Results/Workshops/Facilitators_Institute/Theory

Ghobadian, A. (1994). Performance measurement in local government concept \& practice. Retrieved March 2018 from www.emeraldinsight.com

Governor's office. (2017). North West Region of Cameroon. Retrieved November 2017 from http://www.northwest-cameroon.com/home-100-inner-85.html

Guangdi, C. \& Fulwood, C. (2013). An Agency Theory Approach to Sovereign Debt Crisis. The International Journal of Business and Finance Research, 7(5), 123-134. 
Hansen S., David T. Otley D. \& Van der Stede W. (2003). Practice Developments in Budgeting: An Overview and Research Perspective. Journal of Management Accounting Research, 15(1), 95-116. https://doi.org/10.2308/jmar.2003.15.1.95

Harelimana, J.B. (2017). The Effect of Budgetary Control on Financial Performance of Kigali Serena hotel in Rwanda. Business Economic Journal, 8, 292.

Hingorani \& Ramanathans S. (2007). Management accounting. New Delhi Indra, Sultan Chad \& Sons 2007. 12. 254-294

Institute of Chartered Accountants of India. (2014). Budgets and budgetary control. Retrieved April 2018 from www.icaiknowledgegateway.org

Kaplan, R.S. \& Norton, D.P. (1992). The Balanced Scorecard: Measures that drive performance. Harvard Business Review, Jan/Feb Ed.

Kyei, E., Kwaning C.O. \& Dontras F. (2015). Budgets and Budgeting Control as a management tool for Ghana Metropolitan Assemblies. Journal of Finance and Accounting, 3(5), 159-163. https://doi.org/10.11648/j.jfa.20150305.17

Lambe, I et al. (2015). A systematic Review of Budgeting and Budgetary Control in Government owned organizations, Research Journal of Finance and Accounting, 6(6).

Lucey, T. (2008). Costing. New York, DP Publications.

Margah, M.P. (2005). Financial Management and Control in Higher Education. New York, Routledgefalme.

Millichamp, A.H. (1997). Auditing: An Introduction Manual for Accounting Students. D.P. Publications, Shepherds Bush Green, London.

Mukah, S.T. (2015). Effects of International Public Sector Accounting Standards Adoption on public sector accounting and financial reporting in Cameroon. African Journal of Social Sciences, 6.

Mukah, S.T. (2016). Factors Influencing the Acceptance of International Public Sector Accounting Standards in Cameroon. Retrieved $2^{\text {nd }}$ December 2017 from www.sciedupress.com/afr

Otley, E.C. \& Merchant, K. (1990). Accounting for management control, 2ed, Chapman and Hall https://en.m.wikipedia.org

Ojo. O. (2009). "Efficient management for local governments: The Nigerian Experience". Bulletinul, Universitajii Pekol - gaze din Ploiesti Vol. LX1 N0.2/2009: 36-44.

Ojofeitimi, T. (2000). "Managing at the grass roots: Local government and rural development in the $21^{\text {st }}$ Century". Lagos, Center for Management Development

Oxford Dictionary of Accounting. (2010). Oxford University Press, www.oup.com

Perrin, R. F. (2012). Human Factors in Budgeting. Retrieved $4^{\text {th }}$ April 2018, from http://www.accountingformanagement.com/human_factors_in_budgeting.htm.

Preetabh. (2010). Advantages of budgetary control. Retrieved February 2018 from $\mathrm{http}: / /$ expertscolumn.com/content/advantages-budgetary-control.

Siyambola, T. T. (2013). The impact of budgeting and budgetary control on the performance of Manufacturing Company in Nigeria. Journal of Business Management and Social Sciences Research, 2(12).

Walker, M. L. (1930). Municipal Expenditures. Baltimore: Johns Hopkins Press. 


\section{Appendices}

\section{Appendix A: Components of Budgetary Control and Performance of the councils}

\section{a) Planning}

\begin{tabular}{|c|c|c|c|c|c|c|}
\hline Statements & $\begin{array}{l}\text { Strongly } \\
\text { disagree }\end{array}$ & Disagree & $\begin{array}{l}\text { Not } \\
\text { decided }\end{array}$ & Agree & $\begin{array}{l}\text { Strongly } \\
\text { agree }\end{array}$ & Total \\
\hline \multirow{2}{*}{$\begin{array}{l}\text { The organisation has long term and short } \\
\text { term budget plans }\end{array}$} & 5 & 0 & 20 & 25 & 50 & \multirow[t]{2}{*}{100} \\
\hline & $5 \%$ & $0 \%$ & $20 \%$ & $25 \%$ & $50 \%$ & \\
\hline \multirow{2}{*}{ The budgets have clear goals and objectives } & 5 & 0 & 20 & 35 & 40 & \multirow[t]{2}{*}{100} \\
\hline & $5 \%$ & $0 \%$ & $20 \%$ & $35 \%$ & $40 \%$ & \\
\hline \multirow{2}{*}{$\begin{array}{l}\text { The budgets cover all the aspects of the council } \\
\text { mission }\end{array}$} & 5 & 0 & 20 & 35 & 40 & \multirow[t]{2}{*}{100} \\
\hline & $5 \%$ & $0 \%$ & $20 \%$ & $35 \%$ & $40 \%$ & \\
\hline \multirow{2}{*}{$\begin{array}{l}\text { The budget, outcome goals and objectives are } \\
\text { linked }\end{array}$} & 0 & 5 & 15 & 45 & 31 & \multirow[t]{2}{*}{96} \\
\hline & $0 \%$ & $5.2 \%$ & $15.6 \%$ & $46.8 \%$ & $32.2 \%$ & \\
\hline \multirow{2}{*}{$\begin{array}{l}\text { The priorities are set for the coming year at } \\
\text { budget conference/Committees. }\end{array}$} & 0 & 0 & 20 & 45 & 35 & \multirow[t]{2}{*}{100} \\
\hline & $0 \%$ & $0 \%$ & $20 \%$ & $45 \%$ & $35 \%$ & \\
\hline
\end{tabular}

b) Participative budgeting

\begin{tabular}{|c|c|c|c|c|c|c|}
\hline Statements & $\begin{array}{l}\text { strongly } \\
\text { disagree }\end{array}$ & disagree & $\begin{array}{l}\text { not } \\
\text { decided }\end{array}$ & agree & $\begin{array}{l}\text { strongly } \\
\text { agree }\end{array}$ & Total \\
\hline \multirow{2}{*}{$\begin{array}{l}\text { Everyone who matters is involved in the budget } \\
\text { preparation process }\end{array}$} & 0 & 5 & 20 & 35 & 40 & \multirow[t]{2}{*}{100} \\
\hline & $0 \%$ & $5 \%$ & $20 \%$ & $35 \%$ & $40 \%$ & \\
\hline \multirow{2}{*}{ All the stakeholders to the budget are involved } & 5 & 5 & 20 & 30 & 35 & \multirow[t]{2}{*}{95} \\
\hline & $5.2 \%$ & $5.2 \%$ & $21 \%$ & $31.5 \%$ & $36.8 \%$ & \\
\hline \multirow{2}{*}{$\begin{array}{l}\text { All departments are always involved in the budgeting } \\
\text { process }\end{array}$} & 10 & 15 & 15 & 30 & 30 & \multirow[t]{2}{*}{100} \\
\hline & $10 \%$ & $15 \%$ & $15 \%$ & $30 \%$ & $30 \%$ & \\
\hline \multirow{2}{*}{ Approved budgets are shared to all departments } & 0 & 5 & 15 & 60 & 20 & \multirow[t]{2}{*}{100} \\
\hline & $0 \%$ & $5 \%$ & $15 \%$ & $60 \%$ & $20 \%$ & \\
\hline \multirow{2}{*}{$\begin{array}{l}\text { The mayor provides leadership and to all the } \\
\text { subordinates throughout the budgetary process }\end{array}$} & 5 & 5 & 20 & 40 & 30 & \multirow[t]{2}{*}{100} \\
\hline & $5 \%$ & $5 \%$ & $20 \%$ & $40 \%$ & $30 \%$ & \\
\hline \multirow{2}{*}{$\begin{array}{l}\text { Each department prepares a budget prior to the overall } \\
\text { budget }\end{array}$} & 5 & 10 & 10 & 40 & 27 & \multirow[t]{2}{*}{92} \\
\hline & $5.4 \%$ & $10.8 \%$ & $10.8 \%$ & $43.5 \%$ & $29.3 \%$ & \\
\hline \multicolumn{7}{|l|}{ c) Responsibility } \\
\hline Statements & $\begin{array}{l}\text { Strongly } \\
\text { disagree }\end{array}$ & Disagree & $\begin{array}{l}\text { Not } \\
\text { decided }\end{array}$ & Agree & $\begin{array}{l}\text { Strongly } \\
\text { agree }\end{array}$ & Total \\
\hline \multirow{2}{*}{ Organizational structure is well specified } & 15 & 10 & 10 & 40 & 25 & \multirow[t]{2}{*}{100} \\
\hline & $15 \%$ & $10 \%$ & $10 \%$ & $40 \%$ & $25 \%$ & \\
\hline \multirow{2}{*}{$\begin{array}{l}\text { Responsibilities are designed per organizational } \\
\text { structure }\end{array}$} & 10 & 15 & 5 & 35 & 25 & \multirow[t]{2}{*}{90} \\
\hline & $11 \%$ & 16.6 & $5.5 \%$ & 38.8 & 27.7 & \\
\hline \multirow{2}{*}{$\begin{array}{l}\text { Reports are prepared to evaluate each responsibility } \\
\text { center's performance }\end{array}$} & 10 & 20 & 15 & 25 & 30 & \multirow[t]{2}{*}{100} \\
\hline & $10 \%$ & $20 \%$ & $15 \%$ & $25 \%$ & $30 \%$ & \\
\hline \multirow{2}{*}{ Responsibility is from top to lower management levels } & 5 & 5 & 5 & 45 & 40 & \multirow[t]{2}{*}{100} \\
\hline & $5 \%$ & $5 \%$ & $5 \%$ & $45 \%$ & $40 \%$ & \\
\hline
\end{tabular}




\section{d) Motivation}

\begin{tabular}{|c|c|c|c|c|c|c|}
\hline Statements & $\begin{array}{l}\text { Strongly } \\
\text { disagree }\end{array}$ & Disagree & $\begin{array}{l}\text { Not } \\
\text { decided }\end{array}$ & Agree & $\begin{array}{l}\text { Strongly } \\
\text { agree }\end{array}$ & Total \\
\hline \multirow{2}{*}{ The salary of employees are satisfactory } & 15 & 5 & 15 & 40 & 20 & \multirow[t]{2}{*}{95} \\
\hline & 15.7 & 5.2 & 17.7 & 42 & 21 & \\
\hline \multirow{2}{*}{ Employees are trained } & 10 & 5 & 10 & 35 & 30 & \multirow[t]{2}{*}{90} \\
\hline & $11 \%$ & $16.6 \%$ & $11 \%$ & $38.8 \%$ & $33.3 \%$ & \\
\hline \multirow{2}{*}{$\begin{array}{l}\text { There exist other services such as health and insurance } \\
\text { in the institution }\end{array}$} & 10 & 0 & 20 & 35 & 35 & \multirow[t]{2}{*}{100} \\
\hline & $10 \%$ & $0 \%$ & $20 \%$ & $35 \%$ & $35 \%$ & \\
\hline
\end{tabular}

\section{e) Communication}

\begin{tabular}{|c|c|c|c|c|c|c|}
\hline Statements & $\begin{array}{l}\text { Strongly } \\
\text { disagree }\end{array}$ & Disagree & $\begin{array}{l}\text { Not } \\
\text { decided }\end{array}$ & Agree & $\begin{array}{l}\text { Strongly } \\
\text { agree }\end{array}$ & Total \\
\hline \multirow{2}{*}{$\begin{array}{l}\text { There is effective communication of various activities } \\
\text { from the top to the bottom and vice versa }\end{array}$} & 5 & 0 & 25 & 25 & 45 & \multirow[t]{2}{*}{100} \\
\hline & $5 \%$ & $0 \%$ & $25 \%$ & $25 \%$ & $45 \%$ & \\
\hline \multirow{2}{*}{ Changes in activities are timely communicated } & 0 & 10 & 20 & 35 & 30 & \multirow[t]{2}{*}{95} \\
\hline & $0 \%$ & $10.5 \%$ & $21 \%$ & 36.8 & 31.5 & \\
\hline \multirow{2}{*}{ There is sensitisation on the budget control process } & 5 & 5 & 20 & 30 & 40 & \multirow[t]{2}{*}{100} \\
\hline & $5 \%$ & $5 \%$ & $20 \%$ & $30 \%$ & $40 \%$ & \\
\hline
\end{tabular}

\section{f) Monitoring and control}

\begin{tabular}{|c|c|c|c|c|c|c|}
\hline Statements & $\begin{array}{l}\text { Strongly } \\
\text { disagree }\end{array}$ & Disagree & $\begin{array}{l}\text { Not } \\
\text { decided }\end{array}$ & Agree & $\begin{array}{l}\text { Strongly } \\
\text { agree }\end{array}$ & Total \\
\hline \multirow{2}{*}{$\begin{array}{l}\text { Managers hold budget conferences/meetings } \\
\text { regularly to review budget performance }\end{array}$} & 5 & 6 & 24 & 36 & 29 & \multirow[t]{2}{*}{100} \\
\hline & $5 \%$ & $6 \%$ & $24 \%$ & $36 \%$ & $29 \%$ & \\
\hline \multirow{2}{*}{ Budget policies are available to check on spending } & 0 & 0 & 15 & 34 & 51 & \multirow[t]{2}{*}{100} \\
\hline & $0 \%$ & $0 \%$ & $15 \%$ & $34 \%$ & $51 \%$ & \\
\hline \multirow{2}{*}{$\begin{array}{l}\text { Control of the budget activities is done by the head of } \\
\text { departments }\end{array}$} & 5 & 10 & 10 & 25 & 50 & \multirow[t]{2}{*}{100} \\
\hline & $5 \%$ & $10 \%$ & $10 \%$ & $25 \%$ & $50 \%$ & \\
\hline \multirow{2}{*}{$\begin{array}{l}\text { The costs of activities are always reviewed by the } \\
\text { executive committee }\end{array}$} & 10 & 5 & 20 & 45 & 20 & \multirow[t]{2}{*}{100} \\
\hline & $10 \%$ & $5 \%$ & $20 \%$ & $45 \%$ & $20 \%$ & \\
\hline \multirow{2}{*}{$\begin{array}{l}\text { Budget performance evaluation reports are prepared } \\
\text { regularly }\end{array}$} & 0 & 10 & 30 & 35 & 25 & \multirow[t]{2}{*}{100} \\
\hline & $0 \%$ & $10 \%$ & $30 \%$ & $35 \%$ & $25 \%$ & \\
\hline \multirow{2}{*}{$\begin{array}{l}\text { Budget deviations are reported to budget } \\
\text { committee/Executives }\end{array}$} & 0 & 5 & 20 & 20 & 37 & \multirow[t]{2}{*}{82} \\
\hline & $0 \%$ & $6 \%$ & $24.3 \%$ & $24.3 \%$ & $45.1 \%$ & \\
\hline \multirow{2}{*}{$\begin{array}{l}\text { Managers always take timely corrective actions when } \\
\text { adverse variances are reported. }\end{array}$} & 0 & 0 & 20 & 61 & 19 & \multirow[t]{2}{*}{100} \\
\hline & $0 \%$ & $0 \%$ & $20 \%$ & $61 \%$ & $19 \%$ & \\
\hline \multirow{2}{*}{$\begin{array}{l}\text { There is a regular follow up on budget plans by the } \\
\text { budget committee/departmental heads }\end{array}$} & 0 & 0 & 19 & 57 & 24 & \multirow[t]{2}{*}{100} \\
\hline & $0 \%$ & $0 \%$ & $19 \%$ & $57 \%$ & $24 \%$ & \\
\hline
\end{tabular}


g) Performance

\begin{tabular}{|c|c|c|c|c|c|c|}
\hline Statements & $\begin{array}{l}\text { Strongly } \\
\text { disagree }\end{array}$ & Disagree & $\begin{array}{l}\text { Not } \\
\text { decided }\end{array}$ & Agree & $\begin{array}{l}\text { Strongly } \\
\text { agree }\end{array}$ & Total \\
\hline \multirow{2}{*}{$\begin{array}{l}\text { The performance of workers has improved with } \\
\text { budgetary control }\end{array}$} & 5 & 5 & 20 & 35 & 29 & \multirow[t]{2}{*}{94} \\
\hline & $5.3 \%$ & $5.3 \%$ & $21.2 \%$ & $37.2 \%$ & $30.8 \%$ & \\
\hline \multirow{2}{*}{$\begin{array}{l}\text { Corruption and mismanagement has reduced with } \\
\text { implementation of budgetary control }\end{array}$} & 10 & 10 & 15 & 25 & 40 & \multirow[t]{2}{*}{100} \\
\hline & $10 \%$ & $10 \%$ & $15 \%$ & $25 \%$ & $40 \%$ & \\
\hline \multirow{2}{*}{$\begin{array}{l}\text { Revenue collection has improved with the application } \\
\text { of budgetary control }\end{array}$} & 5 & 5 & 8 & 46 & 35 & \multirow[t]{2}{*}{99} \\
\hline & $5 \%$ & $5 \%$ & $8 \%$ & $46.4 \%$ & $35.3 \%$ & \\
\hline \multirow[t]{2}{*}{ Project execution has improved with budgetary control } & 2 & 15 & 15 & 25 & 43 & \multirow[t]{2}{*}{100} \\
\hline & $2 \%$ & $15 \%$ & $15 \%$ & $25 \%$ & $43 \%$ & \\
\hline
\end{tabular}

Source: Author's computation

Appendix B: Budgetary Control Challenges in councils

\begin{tabular}{|c|c|c|c|c|c|c|c|}
\hline SN & Variables & $\begin{array}{l}\text { Strongly } \\
\text { disagree }\end{array}$ & Disagree & $\begin{array}{l}\text { Not } \\
\text { decided }\end{array}$ & Agree & $\begin{array}{l}\text { Strongly } \\
\text { agree }\end{array}$ & Total \\
\hline \multirow[t]{2}{*}{1} & \multirow{2}{*}{$\begin{array}{l}\text { Budgetary control puts too much } \\
\text { pressure on employees. }\end{array}$} & 10 & 40 & 10 & 10 & 30 & \multirow[t]{2}{*}{100} \\
\hline & & $10 \%$ & $40 \%$ & $10 \%$ & $10 \%$ & $30 \%$ & \\
\hline \multirow[t]{2}{*}{2} & \multirow[t]{2}{*}{ Budgetary control creates conflicts. } & 6 & 30 & 30 & 24 & 10 & \multirow[t]{2}{*}{100} \\
\hline & & $6 \%$ & $30 \%$ & $30 \%$ & $24 \%$ & $10 \%$ & \\
\hline \multirow[t]{2}{*}{3} & \multirow{2}{*}{$\begin{array}{l}\text { Competitive realities and changing } \\
\text { environment. }\end{array}$} & 8 & 40 & 10 & 20 & 22 & \multirow[t]{2}{*}{100} \\
\hline & & $8 \%$ & $40 \%$ & $10 \%$ & $20 \%$ & $22 \%$ & \\
\hline \multirow[t]{2}{*}{4} & \multirow{2}{*}{$\begin{array}{l}\text { Exaggerated expenses and understated } \\
\text { income. }\end{array}$} & 0 & 20 & 10 & 40 & 20 & \multirow[t]{2}{*}{90} \\
\hline & & $0 \%$ & $22.22 \%$ & $11.11 \%$ & $44.44 \%$ & $22.22 \%$ & \\
\hline \multirow[t]{2}{*}{5} & \multirow[t]{2}{*}{ Uncommitted staff. } & 0 & 10 & 20 & 30 & 40 & \multirow[t]{2}{*}{100} \\
\hline & & $0 \%$ & $10 \%$ & $20 \%$ & $30 \%$ & $40 \%$ & \\
\hline \multirow[t]{2}{*}{6} & \multirow[t]{2}{*}{ Workers' poor work attitude. } & 0 & 11 & 10 & 40 & 38 & \multirow[t]{2}{*}{99} \\
\hline & & $0 \%$ & $11.11 \%$ & $10.10 \%$ & $40.40 \%$ & $38.38 \%$ & \\
\hline \multirow[t]{2}{*}{7} & \multirow{2}{*}{$\begin{array}{l}\text { Inadequate qualified and experienced } \\
\text { finance personnel. }\end{array}$} & 0 & 0 & 10 & 50 & 40 & \multirow[t]{2}{*}{100} \\
\hline & & $0 \%$ & $0 \%$ & $10 \%$ & $50 \%$ & $40 \%$ & \\
\hline \multirow[t]{2}{*}{8} & \multirow[t]{2}{*}{ Inadequate financial resources. } & 0 & 11 & 0 & 49 & 40 & \multirow[t]{2}{*}{100} \\
\hline & & $0 \%$ & $11 \%$ & $0 \%$ & $49 \%$ & $40 \%$ & \\
\hline \multirow[t]{2}{*}{9} & \multirow[t]{2}{*}{ Financial improprieties. } & 0 & 0 & 16 & 69 & 10 & \multirow[t]{2}{*}{95} \\
\hline & & $0 \%$ & $0 \%$ & $16.84 \%$ & $72.63 \%$ & $10.53 \%$ & \\
\hline \multirow[t]{2}{*}{10} & \multirow{2}{*}{$\begin{array}{l}\text { Lack of resource } \\
\text { knowledge by mayors. }\end{array}$} & 0 & 0 & 10 & 49 & 38 & \multirow[t]{2}{*}{97} \\
\hline & & $0 \%$ & $0 \%$ & $10.31 \%$ & $50.51 \%$ & $39.18 \%$ & \\
\hline \multirow[t]{2}{*}{11} & \multirow{2}{*}{$\begin{array}{l}\text { Unlawful interference by supervisory } \\
\text { authorities. }\end{array}$} & 0 & 0 & 20 & 20 & 59 & \multirow[t]{2}{*}{99} \\
\hline & & $0 \%$ & $0 \%$ & $20.20 \%$ & $20.20 \%$ & $59.6 \%$ & \\
\hline
\end{tabular}

Source: Author's computation 